\title{
PENGENDALIAN HAMA KUMBANG LOGONG (Sitophylus oryzae L.) DENGAN MENGGUNAKAN EKSTRAK BIJI PANGI (Pangium edule Reinw.)
}

\author{
CONTROL OF BEETLE PEST LOGONG (Sitophylusoryzae L.) UTILIZED PANGI (Pangium \\ edule Reinw.) SEED EXCTRACT
}

\author{
Ernest H. Sakul1), Jacklin S.S. Manoppo'), DalvianTaroreh1), Revfly I.F. Gerungan2), dan \\ Sanusi Gugule2) \\ 1Program Studi Biologi Program Pascasarjana Universitas Negeri Manado \\ 2Departemen Biologi FMIPA Univeristas Negeri Manado
}

\begin{abstract}
The research was aimed to prove the effectiveness of seed extract pangi (Pangium edule Reinw.) In increasing mortality of rice-weevil or logong (Sitophylus oryzae L.) using the solvent $n$-hexane fraction and the fraction of ethanol, and then evaporated with a rotary evaporator to obtain viscous extract. This research was conducted in the Chemistry Laboratory of MIPA Manado State University and mini green house Gapoktan Pinaesaan Tonsealama Village during the months of January, February and March 2012 using an experimental method in a plastic box using Completely Randomized Design (CRD) with six treatments were repeated four times, so the total experimental units were 24 units. Each plastic box filled with 20 of rice-weevil or logong adult and any treatment administered doses of: 2.5 ppm, 5.0 ppm, $7.5 \mathrm{ppm}, 15 \mathrm{ppm}, 30 \mathrm{ppm}$ and $45 \mathrm{ppm}$. The results indicate that pangi seed extract is very effective in improving mortality of rice-weevil or logong, where the concentration of the extract $45 \mathrm{ppm}$ is the best pangi seed extract. Test results of Phytochemical Test showed that secondary metabolite of pangi seed extract with $\mathrm{n}$-hexane solvent contains alkaloid compounds and pangi seed extract with ethanol solvent containing phenolic compounds, saponins and tannins.

Keywords : extracts, maseration, Pangium edule Reinw., Sitophylus oryzae L., n-heksan fraction, ethanol fraction, bioinsecticide
\end{abstract}

\section{ABSTRAK}

Penelitian ini bertujuan untuk membuktikan efektifitas ekstrak biji pangi (Pangium edule Reinw.) dalam meningkatkan mortalitas kumbang logong dengan menggunakan pelarut fraksi n-heksan maupun fraksi etanol, kemudian dievaporasi dengan rotary evaporator guna mendapatkan ekstrak kental. Penelitian ini dilaksanakan di laboratorium kimia FMIPA Universitas Negeri Manado dan mini green house Gapoktan Pinaesaan Desa Tonsealama selama bulan Januari, Februari dan Maret 2012 dengan menggunakan metode eksperimen pada kotak plastik menggunakan rancangan acak lengkap (RAL) dengan 6 perlakukan yang diulang sebanyak 4 kali sehingga total unit percobaan sebanyak 24 unit percobaan. Masing-masing kotak plastik diisi dengan 20 ekor kumbang logong dewasa dan setiap perlakuan diberikan dosis 2,5 ppm, 5,0 ppm, 7,5 ppm, 15 ppm, 30 ppm, dan 45 ppm. Hasil penelitian menunjukkan bahwa ekstrak biji pangi sangat efektif dalam meningkatkan mortalitas hama kumbang logong dimana pada konsentrasi ekstrak sebesar 45 ppm merupakan konsentrasi ekstrak biji pangi yang terbaik dalam penelitian ini. Hasil pemeriksaan uji fitokimia menunjukkan bahwa metabolit sekunder dari ekstrak biji pangi dengan pelarut $n$-heksan mengandung senyawa alkaloid dan ekstrak biji pangi dengan pelarut etanol mengandung senyawa fenol, saponin dan tanin.

Kata kunci : ekstrak, maserasi, Pangium edule Reinw., Sitophylus oryzae L., fraksi n-heksan, fraksi etanol, insektisida nabati 


\section{PENDAHULUAN}

Beras dan jagung merupakan salah satu padian paling penting di dunia untuk dikonsumsi manusia. Beras dan jagung adalah bahan makanan pokok bagi sebagian besar penduduk Indonesia. Di negara-negara Asia yang penduduknya padat, khususnya Bangladesh, Myanmar, Kamboja, Cina, Indonesia, Korea, Laos, Filipina, Sri Lanka, Thailand dan Vietnam, beras merupakan pangan pokok. Sebanyak $75 \%$ masukan dan kebutuhan kalori harian masyarakat di negara-negara Asia tersebut berasal dari beras dan jagung. Lebih dari $50 \%$ penduduk dunia tergantung pada beras sebagai sumber kalori utama (Ramsiks, 2010) .

Setelah berlangsungnya masa panen tanaman pangan dan perkebunan, hama serangga baik berupa telur, larva atau ulat banyak yang terbawa ke dalam tempat penyimpanan disamping hama-hama lainnya seperti tikus, burung dan bermacam-macam serangga.

Gudang sebagai sarana yang digunakan untuk penyimpanan bahan baku dan produk jadi merupakan media yang sangat baik untuk perkembangan hama jika tidak ada program manajemen untuk pengendalian faktor-faktor yang berpotensi menurunkan kualitas produk yang disimpan.

Menurut FAO, kehilangan hasil panen di negara-negara berkembang berkisar antara 10$13 \%$, diantaranya berkisar $5 \%$ oleh berbagai jenis hama gudang seperti serangga, tikus, tungau, burung, dan jasad renik. Bulog memperkirakan susut bobot beras sekitar $25 \%$, terdiri dari $8 \%$ waktu panen, $5 \%$ waktu pengangkutan, $2 \%$ waktu pengeringan, 5\% waktu penggilingan, dan 5\% waktu penyimpanan (Ramsiks, 2010).

Penyimpanan beras dan bahan pangan lain, merupakan salah satu mata rantai kegiatan pasca panen sebelum komoditas di distribusikan. Kehilangan komoditas berupa menurunnya mutu, bertambahnya kadar air, kotoran benda asing, kerusakan bentuk, warna, bau, rasa, dan kehilangan kualitas berupa penyusutan berat harus diperhatikan selama penyimpanan.

Salah satu hama pengganggu hasil panen adalah kumbang atau kutu beras (Sitophylus oryzae L.) yang termasuk famili Curculionidae dari genus Sitophilus. Di Sulawesi Utara hama ini disebut logong dan di Minahasa disebut lowona. Hama ini tersebar di tempat atau daerah-daerah yang beriklim tropis dan subtropis, terutama di tempat-tempat atau daerah yang terdapat simpanan produk kesukaannya seperti padi, jagung, ubi jalar dan kacang hijau. Serangga yang banyak merusak hasil pertanian terutama dari jenis kumbang Coleoptera yaitu $S$. oryzae $L$. dan Tribolium sp. Hama yang lain yang menyerang beras adalah tikus, burung, tungau dan lain-lain. Bentuk serangga dewasa umumnya mempunyai sayap dan berkembang biak dengan cara bertelur. Siklus hidupnya melampaui beberapa fase kehidupan mulai dari telur, ulat (larva), kepompong (pupa) dan selanjutnya menjadi serangga dewasa. Kumbang dewasa dan bentuk ulatnya sangat aktif merusak bahan simpan (Parinduri, 2010).

Selanjutnya Parinduri (2010) mengemukakan bahwa $S$. oryzae L. merupakan salah satu hama penting dalam gudang. Selama perkembangan dari telur sampai imago dapat menurunkan produksi sampai $20 \%$ dalam waktu 5 minggu. Faktor yang menentukan derajat kerusakan beras oleh S. oryzae L. dalam masa penyimpanan antara lain oleh pengaruh populasi, varietas asal beras, serta lama penyimpanan beras. $S$. oryzae $L$. adalah salah satu serangga perusak yang menimbulkan kerusakan secara fisik dan mikrobiologis (mutu dan rasa) yang berasal dari Ordo Coleoptera selama pada tempat penyimpanan.

Perlindungan terhadap penyimpanan produk pertanian dari ancaman hama serangga biasanya bergantung pada insektisida buatan seperti contoh organoklor, organofosfat dan karbamat (Sukandar dkk., 2007).

Penggunaan pestisida sintetik yang tidak bijaksana akan merusak lingkungan dan kesehatan manusia. Hal ini terjadi karena tidak semua pestisida yang digunakan mampu menangani organisme penganggu tanaman (OPT) sasaran, selain itu juga dapat membunuh biota-biota yang mungkin masih berguna bagi. Salah satu tujuan praktis sistem pengendalian hama terpadu adalah mengurangi kuantum penggunaan pestisida sintetik antara lain dengan mengintroduksikan pestisida nabati yang mampu menandingi kemampuan 
pestisida sintetik tersebut (Suryaningsih dan Hadisoeganda, 2004).

Pengendalian hama $S$. oryzae dan $T$. castaneum sampai sekarang ini masih menggunakan pestisida dan fumigasi. Fumigant yang digunakan dalam fumigasi di gudang-gudang Bulog saat ini terdiri dari Phosphine dan Metyl bromide. Penggunaan pestisida kimia dalam pengendalian hama saat ini banyak menimbulkan dampak negatif. Masalah pencemaran lingkungan merupakan akibat yang jelas terlihat, selain itu penggunaan pestisida kimia di Indonesia telah memusnahkan $55 \%$ jenis hama dan $72 \%$ agen pengendali hayati.

Kumbang bubuk beras yang juga biasa disebut kumbang penggerek beras. Kumbang ini merupakan hama utama pada beras yang disimpan. Serangannya ditandai dengan butir beras berlubang-lubang atau menjadi tepung karena gerekan kumbang. Akibat hama ini beras dapat kehilangan berat hingga mencapai $23 \%$ setelah disimpan beberapa bulan.

Kondisi gudang penyimpanan cadangan pangan Gapoktan Pinaesaan Desa Tonsealama dari data yang tercatat pada kondisi hingga akhir Juni 2011, terlihat bahwa proses penyerangan hama gudang jenis kumbang logong ( $S$. oryzae) diperkirakan sekitar 50 - 60\% dapat ditemukan Kumbang logong (S. oryzae L.) pada setiap karung penyimpanan beras atau jagung atau tepung. Populasi hama tersebut lama kelamaan meningkat dengan cepat seiring dengan lambatnya proses pemasaran pada konsumen sehingga cadangan pangan bertumpuk. Hal ini menjadi penyebab bertambah cepatnya susut bahan cadangan pangan yang dikumpulkan oleh para petani yang tergabung dalam Gapoktan Pinaesaan Desa Tonsealama, Tondano Utara (Manoppo, 2011 komunikasi personal).

Namun demikian, penggunaan insektisida buatan secara terus menerus dapat mengakibatkan pencemaran lingkungan, sehingga diperlukan suatu sarana pengendalian hama lain yang ramah lingkungan. Melihat kondisi di atas, maka tujuan utama dalam penelitian ini adalah untuk membuktikan toksisitas kerja dari ekstrak biji ( $P$. edule Reinw.) sebagai insektisida nabati dalam meningkatkan mortalitas (tingkat kematian) hama kumbang logong (S. oryzae L.).

\section{METODE PENELITIAN}

Buah pangi atau Pangium edule Reinw. yang telah tua (berwarna coklat tua) diperoleh dari pohon pangi yang tumbuh pada ketinggian $300 \mathrm{~m}$ dpl di Desa Tonsealama, Tondano Utara, Minahasa.

Pelarut dan pereaksi yang digunakan adalah etanol, $n$-heksan. Bahan kimia yang digunakan adalah pada derajat pro analisis.

Seperangkat alat ekstraksi, rotavapor (Buchi R-250), blender (Miyako), desikator, oven, timbangan digital (Ohauss) digunakan dalam penelitian ini.

\section{Prosedur Awal}

Biji pangi segar dikeluarkan daging buahnya, dicuci sampai bersih, kemudian kulit biji dipecah dengan palu untuk mengambil daging biji, kemudian daging biji dikeringanginkan pada suhu ruang tanpa dijemur langsung pada sinar matahari langsung.

Biji pangi yang telah ditumbuk dan dihancurkan hingga kecil kemudian harus melewati proses pengeringan sebelum dilakukan pembuatan ekstrak kental. Proses pengeringan dengan menggunakan kipas angin kira-kira 1-2 minggu. Penggunaan kipas angin dimaksudkan untuk mencegah terjadinya pembentukan jamur dalam sampel yang akan diujicobakan.

Kemudian dilanjutkan dengan uji kandungan air pada sampel biji pangi. Proses penentuan dan pemeriksaan kadar air suatu bahan dalam analisis sangat diperlukan untuk melihat seberapa banyak air yang ada dan terkandung dalam sampel yang akan dianalisis dan yang akan dibuat ekstrak, juga digunakan untuk melihat tingkat kering suatu bahan.

\section{Uji Penentuan Kadar Air Pada Biji Pangi}

Penentuan kadar air suatu bahan dalam analisis diperlukan untuk melihat seberapa banyak air yang ada dan terkandung dalam sampel yang akan dianalisis. Pengukuran kadar air dilakukan 
dengan metode oven. Sebanyak \pm 3 gram sampel biji pangi ditimbang dalam cawan porselen yang telah ditimbang dan diketahui bobotnya. Pengeringan bahan dilakukan dengan oven agar kestabilan suhu dan waktu pengeringan lebih terkontrol. Kemudian sampel biji pangi dikeringkan ke dalam oven bersuhu $\pm 105^{\circ} \mathrm{C}$ selama 5 jam, kemudian didinginkan di dalam desikator dan ditimbang sampai bobotnya konstan.

\section{Ekstraksi Biji Pangi Melalui Proses Maserasi dengan Pelarut $\mathrm{n}$-heksana}

Serbuk biji atau hancuran biji pangi yang telah dihaluskan tersebut, kemudian dimasukkan ke dalam stoples dan dimaserasi dengan ditambah pelarut $n$-heksana sebanyak 1 liter. Campuran ini kemudian dikocok-kocok supaya tercampur rata dan didiamkan selama 1 × 24 jam untuk maserasi tahap 1. Setelah maserasi selesai, hasil maserasi tahap 1 dihasilkan berupa filtrat dan ampas yang memiliki warna coklat keruh Kemudian ampas biji pangi tersebut, dimaserasi tahap kedua dengan pelarut $n$-heksana sebanyak $800 \mathrm{ml}$. Campuran ini kemudian digojog-gojog supaya tercampur rata dan didiamkan selama $1 \times 24$ jam untuk proses maserasi tahap 2.

Kemudian pada tahap maserasi kedua, diperoleh filtrat kedua dan ampas biji pangi yang memiliki warna coklat terang (tidak keruh) dan batas antara filtrat serta ampas dapat dilihat dengan jelas. Hasil filtrat pada maserasi kedua digabungkan dengan filtrat pertama. Kemudian ampas biji pangi tersebut dimaserasi tahap ketiga dengan n-heksana sebanyak $500 \mathrm{ml}$. Campuran ini kemudian digojog-gojog supaya tercampur rata dan didiamkan selama 1 x 24 jam untuk maserasi tahap 3.

Filtrat hasil proses maserasi dari tahap 1 hingga tahap 3 yang telah diperoleh, disaring dengan menggunakan kertas saring Whatmann No. 42 dan menggunakan pompa vakum untuk mempercepat proses penyaringan filtrat dan dihasilkan filtrat $n$-heksan berwarna kuning bening.

Proses penyaringan filtrat dilakukan sampai seluruh filtrat hasil maserasi tersaring dengan baik dan sempurna, kemudian filtrat yang telah disaring, kemudian dipindahkan ke dalam labu erlenmeyer khusus yang akan digunakan pada rotary evaporator dan siap dilakukan proses evaporasi.

Filtrat yang telah diperoleh, dipekatkan dengan menggunakan rotary evaporator pada suhu $40^{\circ} \mathrm{C}$, untuk menghilangkan pelarutnya sehingga didapatkan ekstrak pekat biji pangi ( $P$. edule) yaitu ekstrak $n$-Hexane biji pangi selama \pm 2 jam.

\section{Ekstraksi Biji Pangi melalui Proses Maserasi dengan Pelarut Etanol}

Hasil residu akhir berupa ampas pada saat maserasi dengan pelarut $n$-heksana, kemudian dimaserasi dengan pelarut etanol (EtOH). Hasil residu tersebut dimasukkan ke dalam bejana erlenmeyer atau stoples untuk dimaserasi dengan ditambah etanol 70\% (Maserasi etanol tahap 1). Adapun etanol yang digunakan adalah Ethanol For Analysis (PA) sebanyak $500 \mathrm{ml}$. Campuran ini kemudian dikocok-kocok supaya larutan tercampur rata dan larutan didiamkan selama 1 × 24 jam untuk bisa menghasilkan rendemen yang baik.

Penggunaan etanol $70 \%$ merupakan pelarut yang bersifat semipolar sehingga diharapkan etanol mampu menarik senyawa-senyawa polar dan semipolar yang terkandung dalam biji pangi.

Filtrat yang dihasilkan pada tahap maserasi 1 , kemudian ditampung pada stoples yang lain. Warna filtrat yang dihasilkan berwarna coklat muda. Ampas atau hasil residu akhir biji $P$. edule yang telah dimaserasi dengan etanol selama $1 \times 24$ jam, diulang pada hari kedua dan hari ketiga dengan cara dikocok-kocok supaya tercampur rata hingga diperoleh masera yang didapat berwarna bening (diasumsikan semua senyawa semi polar dan polar tertarik oleh pelarut etanol) dan diperoleh hasil filtrat etanol.

Hasil filtrat pada maserasi pertama, kedua dan ketiga digabungkan ke dalam sebuah labu erlenmeyer besar. Filtrat yang telah diperoleh dipekatkan dengan menggunakan rotary evaporator pada suhu $40^{\circ} \mathrm{C}$ dengan jalan dilakukan proses evaporasi, alat ini menggunakan pendingin dan dirangkaikan dengan labu erlenmeyer dan alat ini digunakan untuk memisahkan pelarut dan ekstrak sehingga didapatkan ekstrak pekat biji pangi $(P$. edule) yaitu ekstrak etanol (EtOH) biji pangi. 
Ketika telah diperoleh kedua jenis ekstrak tersebut yaitu ekstrak biji pangi n-heksan dan ekstrak biji pangi etanol, kemudian dilakukan uji $\mathrm{LC}_{50}$ pada hama kumbang logong jagung ( $S$. zeamais), dengan tingkat konsentrasi (1.0, 2.5. 5.0, 7.5 dan 10 ppm), Pada saat telah diperoleh hasil uji $\mathrm{LC}_{50}$, dimana mortalitas tertinggi diperoleh pada salah satu fraksi yang diujikan, langkah selanjutnya fraksi yang paling tinggi jumlah mortalitas dijadikan patokan untuk diaplikasikan dengan menggunakan perlakuan berbasis rancangan acak lengkap.

\section{HASIL DAN PEMBAHASAN}

\section{Penghitungan Kadar Air Biji Pangi}

Penghitungan kadar air dapat diukur dengan rumus :

Kadat air $\left.(\%)=\frac{\text { Bcbol awal }- \text { bobul akhii }}{\text { Bcbot Awal }} \times 101\right) \%$

Hasil penghitungan sebagai berikut: Berat cawan porselen besar sebesar 73.002 gram. Berat cawan porselen besar + sampel biji pangi sebelum pemanasan sebesar 74.102 gram, Berat cawan porselen besar + sampel biji pangi setelah pemanasan sebesar 74.003 gram, Berat awal/ berat cawan $=74.102 / 73.002$ gram $=1.100$ gram, Berat akhir $/$ berat cawan $=74.003 / 73.002$ gram $=1.001$ gram. Kadar air $(\%)=0.1 / 1.1 \times 100 \%=9,0909 \%$

Hasil penentuan kadar air biji pangi kering oven menunjukkan kadar air rata-rata yang diperoleh sebesar $9.0909 \%$. Karena kadar air dibawah $10 \%$, telah tercapai maka tahapan selanjutnya yaitu melakukan maserasi awal dengan menggunakan pelarut $\mathrm{n}$-heksan.

Uji LC 50 (Lethal Concentration) dari Aktivitas Bioinsektisida Ekstrak Biji Pangi terhadap Sitophylus zeamais

Pengujian aktivitas bioinsektisida yang diperoleh dari ekstrak biji pangi baik yang menggunakan pelarut n-heksan maupun pelarut etanol, dilakukan terhadap kumbang logong dari genus yang sama dengan $S$. oryzae yaitu genus Sitophylus namun spesies yang berbeda yaitu $S$. zeamais (kumbang logong yang menyerang jagung).

Uji $\mathrm{LC}_{50}$ dilakukan untuk mengukur tingkat mortalitas kumbang logong. $\mathrm{LC}_{50}$ merupakan uji aplikasi konsentrasi ekstrak dalam lingkungan di mana jumlah bahan yang diaplikasi menyebabkan kematian $50 \%$ dari kelompok hewan uji.

Hasil LC $_{50}$ dari ekstrak biji pangi yang menggunakan pelarut $\mathrm{n}$-heksan dan pelarut etanol terhadap kumbang logong $\mathrm{S}$. oryzae ditunjukkan pada Tabel 1.

Hasil analisis probit dengan menggunakan SPSS IBM 20, diperoleh angka pada taraf 50\% sebesar 12,711 dimana nilai $\mathrm{LC}_{50}$ hasil analisis probit yang diperoleh kurang dari $1000 \mu \mathrm{g} / \mathrm{ml}$. berada pada kisaran kategori toxic dimana rentang nilai LC50 yaitu 12,711 berada pada kisaran nilai $10-100 \mathrm{mg} / \mathrm{L}$.

Tabel 1. Hasil Uji LC ${ }_{50}$ Pada Kumbang Logong S. oryzae

(Table 1. Result test $L C_{50}$ for Rice-Weevil Logong S. oryzae)

\begin{tabular}{|c|c|c|}
\hline \multirow[b]{2}{*}{ Perlakuan } & \multicolumn{2}{|c|}{ (Lethal Concentration/LC $\left.{ }_{50}\right)$ Kumbang Logong S. zeamais } \\
\hline & $\begin{array}{l}\text { Ekstrak Biji Pangi dengan Pelarut n- } \\
\text { heksan }\end{array}$ & $\begin{array}{c}\text { Ekstrak Biji Pangi dengan Pelarut } \\
\text { Etanol }\end{array}$ \\
\hline $1 \mathrm{ppm}$ & 5 ekor & 2 ekor \\
\hline $2.5 \mathrm{ppm}$ & 5 ekor & 3 ekor \\
\hline $5.0 \mathrm{ppm}$ & 8 ekor & 3 ekor \\
\hline $7.5 \mathrm{ppm}$ & 10 ekor & 4 ekor \\
\hline 10 ppm & 10 ekor & 5 ekor \\
\hline Jumlah & 38 ekor & 17 ekor \\
\hline Total Hewan Uji & 50 ekor & 50 ekor \\
\hline Prosentase Kematian & $38 / 50 \times 100 \%=76 \%$ & $17 / 50 \times 100 \%=37 \%$ \\
\hline
\end{tabular}


Hasil Uji Aplikasi Ekstrak Biji Pangi pada Kumbang Logong Berbasis Rancangan Acak Lengkap Analisis Varians

\section{Jumlah Kumbang Logong Yang Mati}

Hasil pengamatan pengaruh aplikasi ekstrak biji pangi dengan pelarut $n$-heksan terhadap tingkat mortalitas kumbang logong yang mengalami kematian disajikan pada Tabel 2.
Perbedaan mortalitas kumbang logong untuk masing-masing perlakuan pada aplikasi pertama dapat diikuti pada Grafik 1.

Perbedaan mortalitas kumbang logong untuk masing-masing perlakuan pada aplikasi kedua dapat diikuti pada Grafik 2.

Berdasarkan data hasil penelitian yang telah diperoleh, diputuskan untuk mengambil data hasil penelitian yang terbaik yaitu tahap 1 .

Tabel 2. Jumlah Kumbang Logong yang Mati pada Tahap Aplikasi Ekstrak Pertama

(Table 2. Total of Rice-weevil Logong Who Died in the First Extract Application)

\begin{tabular}{ccccccc}
\hline \multirow{2}{*}{ Ulangan } & \multicolumn{7}{c}{ Perlakuan } \\
\cline { 2 - 7 } & $\begin{array}{c}\text { E1 } \\
(2,5 \mathrm{ppm})\end{array}$ & $\begin{array}{c}\text { E2 } \\
(5 \mathrm{ppm})\end{array}$ & $\begin{array}{c}\text { E3 } \\
(7.5 \mathrm{ppm})\end{array}$ & $\begin{array}{c}\text { E4 } \\
(15 \mathrm{ppm})\end{array}$ & $\begin{array}{c}\text { E5 } \\
(30 \mathrm{ppm})\end{array}$ & $\begin{array}{c}\text { E6 } \\
(45 \mathrm{ppm})\end{array}$ \\
\hline 1 & 4 & 6 & 10 & 14 & 18 & 20 \\
2 & 5 & 7 & 8 & 12 & 15 & 20 \\
3 & 6 & 6 & 8 & 10 & 16 & 19 \\
4 & 5 & 5 & 9 & 15 & 18 & 20 \\
Jumlah & 20 & 24 & 35 & 51 & 67 & 79 \\
Rata-rata & 5,00 & 6,00 & 8,75 & 12,75 & 16,75 & 19,75 \\
\hline
\end{tabular}

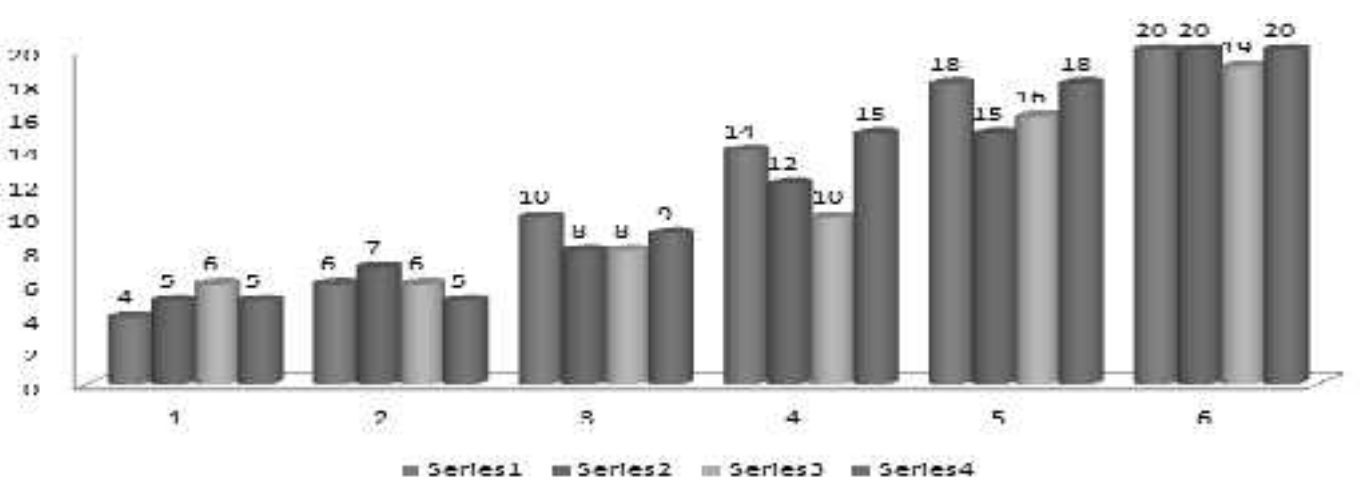

Keterangan : warna biru merupakan ulangan ke-1, merah ulangan ke-2, hijau ulangan ke-3 dan ungu ulangan ke-4).

Grafik 1. Jumlah Kumbang Logong yang Mati pada Tahap Aplikasi Ekstrak Pertama

(Graph 1. Total of Rice-Weevil Logong Who Died in the First Exctrct Application)

Tabel 3. Jumlah Kumbang Logong yang Mati pada Tahap Aplikasi Ekstrak Kedua

(Table 3. Total of Rice-Weevil Logong Who Died in the Second Exctract Application)

\begin{tabular}{ccccccc}
\hline \multirow{2}{*}{ Ulangan } & \multicolumn{7}{c}{ Perlakuan } \\
\cline { 2 - 7 } & $\begin{array}{c}\text { E1 } \\
(2,5 \mathrm{ppm})\end{array}$ & $\begin{array}{c}\text { E2 } \\
(5 \mathrm{ppm})\end{array}$ & $\begin{array}{c}\text { E3 } \\
(7.5 \mathrm{ppm})\end{array}$ & $\begin{array}{c}\text { E4 } \\
(15 \mathrm{ppm})\end{array}$ & $\begin{array}{c}\text { E5 } \\
(30 \mathrm{ppm})\end{array}$ & $\begin{array}{c}\text { E6 } \\
(45 \mathrm{ppm})\end{array}$ \\
\hline 1 & 2 & 4 & 6 & 9 & 15 & 20 \\
2 & 3 & 5 & 5 & 7 & 14 & 20 \\
3 & 4 & 5 & 5 & 8 & 11 & 20 \\
4 & 3 & 4 & 6 & 10 & 12 & 20 \\
Jumlah & 12 & 18 & 22 & 34 & 52 & 80 \\
Rata-rata & 3,00 & 4,50 & 5,50 & 8,50 & 13,00 & 20,00 \\
\hline
\end{tabular}




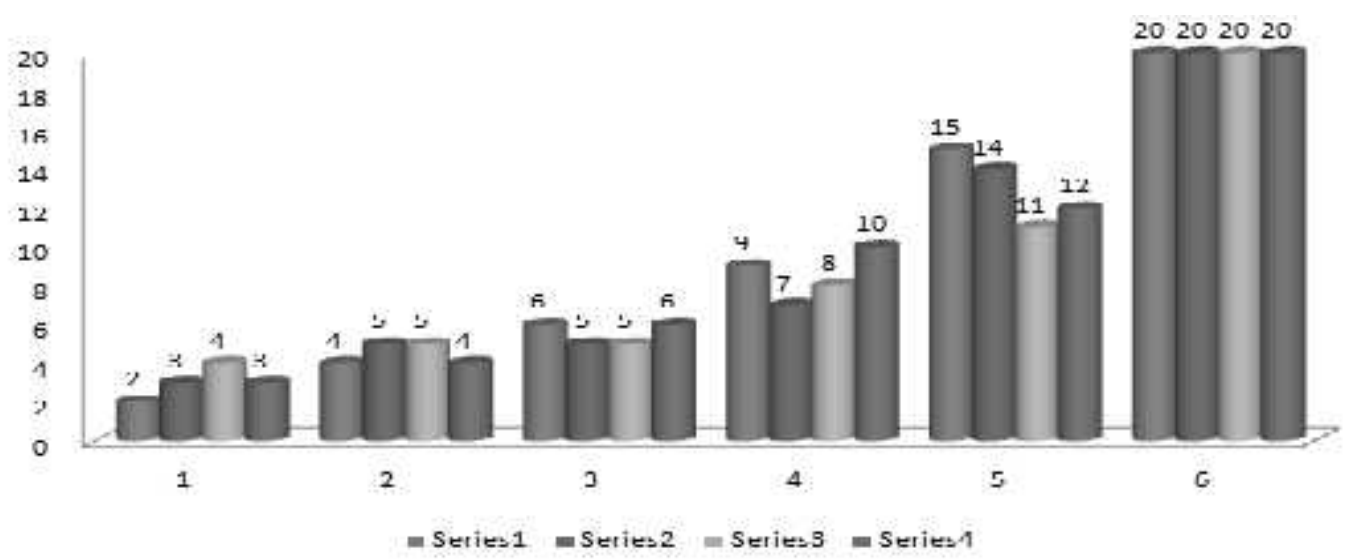

Keterangan : warna biru merupakan ulangan ke-1, merah ulangan ke-2, hijau ulangan ke-3 dan ungu ulangan ke-4).

Grafik 2. Jumlah Kumbang Logong yang Mati pada Tahap Aplikasi Ekstrak Kedua

(Graph 2. Total of Rice Weevil Logong Who Died in the Second Esctract Application)

Data hasil penelitian yang diperoleh telah diuji kenormalan datanya melalui uji kenormalan data menurut Kolmogorov-Smirnov test dimana hipotesis statistik kenormalan data yang hendak diuji adalah: Data tingkat mortalitas kumbang logong yang diberi ekstrak biji pangi menyebar secara normal.

Setelah uji kenormalan data dilanjutkan pada tahap selanjutnya Uji Kesamaan Variansi (Uji Kehomogenan Ragam). Pengujian kesamaan dua ragam dilakukan dengan Levene's test dan hasilnya data memiliki kesamaan variansi.

\section{Analisis Sidik Ragam (ANOVA)}

Karena persyaratan kenormalan data dan uji homogenitas dapat dipenuhi. Oleh karena itu data hasil penelitian diuji dengan menggunakan Analisis Ragam (ANOVA) Uji $F$ guna menguji perbedaan yang terjadi pada setiap perlakuan yang diujicobakan pada taraf nyata $5 \%$.

Oleh karena nilai F-Hitung $=88,014$ lebih besar dari F-Tabel $=2,77$ pada taraf nyata $5 \%$, maka diputuskan untuk menolak Ho yang berarti ada pengaruh yang nyata dari perlakuan konsentrasi ekstrak biji pangi terhadap kecepatan mortalitas kumbang logong.

Untuk melihat perbedaan pengaruh antar perlakuan maka diputuskan untuk diuji lanjut dengan menggunakan Uji Beda Nyata Terkecil (BNT) pada taraf nyata $95 \%$ atau $\alpha 0.05$.

Hasil uji BNT menunjukkan bahwa pada perlakuan $\mathrm{B} 6$ dengan konsentrasi ekstrak biji pangi dengan pelarut $\mathrm{n}$-heksan sebesar $45 \mathrm{ppm}$, terlihat perbedaan yang signifikan antara perlakuan B6 (45 ppm) tersebut dengan perlakuan-perlakuan lainnya yang telah diujicobakan pada unit percobaan.

\section{Pengaruh Polaritas Pelarut Terhadap Rendemen dan Karakter Ekstrak}

Ekstraksi biji pangi dengan metode kering yang menggunakan dua jenis pelarut yaitu pelarut n-heksan dan pelarut etanol menunjukkan hasil yang berbeda secara nyata dalam proses uji $\mathrm{LC}_{50}$. Penggunaan dua jenis pelarut dimaksudkan untuk melebarkan jangkauan kepolaran agar senyawasenyawa yang non-polar sampai polar terekstraksi semua (Harborne, 1987).

Tujuan lain adalah untuk mengetahui ekstrak kasar yang mempunyai aktivitas insektisida paling tinggi. Jumlah ekstrak yang terkumpul dinyatakan dengan rendemen. Rendemen menunjukkan efektivitas pelarut tertentu terhadap bahan dalam suatu sistem ekstraksi (Tabel 5). 
Tabel 4. Hasil Analisis Sidik Ragam

(Table 4. Result of Analysis of Variance)

ANOVA

Jumlah Kumbanq "Logonq" (Sitophylus orvzac) Yanq Matı

\begin{tabular}{|l|r|r|r|r|r|}
\hline & \multicolumn{1}{|c|}{$\begin{array}{c}\text { Sum of } \\
\text { Squares }\end{array}$} & df & Mean square & \multicolumn{1}{c|}{ F } & \multicolumn{1}{c|}{ sig } \\
\hline Metween Croups & 709,000 & 5 & 141,000 & nn,014 & 000 \\
Within Groups & 29,000 & 18 & 1,611 & & \\
Total & 738,000 & 23 & & & \\
\hline
\end{tabular}

Tabel 5. Rendemen Kering Ekstrak Biji Pangi (P. Edule Reinw)

(Table 5. The Dry Yield of Pangi (P. Edule Reinw) Seed Exctract)

\begin{tabular}{|c|c|c|c|}
\hline \multirow[b]{2}{*}{ No. } & \multirow[b]{2}{*}{ Berat Bahan (500 gram) } & \multicolumn{2}{|c|}{ Ekstrak (1000 ml) } \\
\hline & & $\begin{array}{c}\text { Pelarut } n \text {-heksan }(g) \text { dan } \\
\text { karakteristik }\end{array}$ & $\begin{array}{c}\text { Pelarut etanol }(\mathrm{g}) \text { dan } \\
\text { karakteristik }\end{array}$ \\
\hline 1. & Biji Pangi Kering & $\begin{array}{c}70,123 \\
\text { Kental, warna coklat tua }\end{array}$ & $\begin{array}{c}86,354 \\
\text { Cairan tidak terlalu kental, } \\
\text { warna coklat muda }\end{array}$ \\
\hline
\end{tabular}

Tabel 6. Hasil Identifikasi Kimia Ekstrak n-heksan dan Ekstrak Etanol $70 \%$ Biji Pangi (P. Edule Reinw)

(Table 6. Chemical Identification Results of $n$-hexan Exctract and Ethanol $70 \%$ Exctract from Pangi seed (P. Edule Reinw))

\begin{tabular}{|c|c|c|c|c|}
\hline No. & $\begin{array}{l}\text { Golongan } \\
\text { Senyawa }\end{array}$ & $\begin{array}{c}\text { Ekstrak n-heksan } \\
\text { Biji Pangi }\end{array}$ & $\begin{array}{l}\text { Ekstrak Etanol } \\
70 \% \text { Biji Pangi }\end{array}$ & Karakteristik \\
\hline 1. & Saponin & - & + & Terbentuk busa stabil selama \pm 30 menit \\
\hline 2. & Tanin & - & + & $\begin{array}{l}\text { Penambahan Gelatin } 10 \% \text { (terbentuk } \\
\text { endapan) } \\
\text { Penambahan } \mathrm{FeCl}_{3} 1 \% \text { (perubahan warna } \\
\text { dari kuning cerah menjadi kuning tua } \\
\text { keruh menuju biru) }\end{array}$ \\
\hline 3. & Fenol & - & + & $\begin{array}{l}\text { Penambahan } \mathrm{FeCl}_{3} 1 \% \text { (perubahan warna } \\
\text { dari kuning menjadi biru) }\end{array}$ \\
\hline
\end{tabular}

Pelarut etanol bersifat semipolar sehingga dapat menarik senyawa-senyawa polar dan semipolar yang terkandung dalam biji pangi kering. Rendemen ekstrak etanol $70 \%$ biji pangi kering diduga sebagian besar mengandung senyawa fenolik, termasuk didalamnya golongan flavonoid, fenol, tanin dan sebagian kecil terpenoid, saponin, alkaloid, dan steroid.

Pada proses ekstraksi biji pangi dengan menggunakan pelarut $n$-heksan, ternyata pelarut tersebut bersifat non-polar, sehingga hanya dapat menarik senyawa non-polar yang mengandung minyak dan lemak seperti tritepenoid, (kamfor, linalool) dan steroid.

\section{Hasil Analisis Komponen Fitokimia}

Pemeriksaan terhadap metabolit sekunder dilakukan untuk senyawa-senyawa antara lain seperti saponin, tanin dan fenol. Hasil screening phytochemistry ditampilkan pada Tabel 6 .

\section{Aktifitas Insektisida Ekstrak Biji Pangi}

Pengujian aktivitas insektisida dilakukan pada kumbang Sitophylus dari spesies yang berbeda dengan hewan uji utama yaitu $S$. zeamais atau kumbang logong yang memiliki habitat di tumpukan jagung. Uji tersebut dirangkaikan dengan pengujian nilai Lethal Concentration ( $\left.\mathrm{LC}_{50}\right)$.

Pada penelitian ini diperoleh data hasil berupa penyemprotan larutan ekstrak biji pangi 
dengan pelarut $\mathrm{n}$-heksan, mencapai jumlah 38 ekor kumbang kumbang logong $S$. zeamais yang mati dari total hewan uji yang dicobakan sebanyak 50 ekor, dengan total persentase yaitu $76 \%$. Sedangkan jumlah mortalitas dari hewan uji yaitu kumbang logong $S$. zeamais yang diberi perlakuan penyemprotan larutan ekstrak biji pangi dengan pelarut etanol, mencapai jumlah 17 ekor kumbang logong $S$. zeamais yang mati dari total hewan uji yang dicobakan sebanyak 50 ekor, dengan total persentase yaitu $34 \%$.

Hasil penelitian menunjukan bahwa ekstrak biji pangi n-heksan kering mempunyai aktivitas tertinggi pada konsentrasi larutan ekstrak sebesar 45 ppm, dimana pada keseluruhan perlakuan B6 ditemukan seluruh hewan uji yaitu kumbang logong jenis Sitophylus oryzae sebesar 20 ekor kumbang per perlakuan, berada dalam keadaan mati. Hal ini sejalan dengan hasil uji $\mathrm{LC}_{50}$ yang mengemukakan bahwa konsentrasi ekstrak biji pangi n-heksan memberi pengaruh yang sangat nyata pada total persentase kematian atau mortalitas kumbang logong sebesar $76 \%$.

Ekstrak biji pangi $\mathrm{n}$-heksan tergolong dalam crude alkaloid exctract dimana ekstrak jenis ini memiliki komponen non-fenolik seperti quindine, indole, terpenoid, quinolizidine, dopamine dan tropane, yang keseluruhannya menunjukan potensi sebagai agen antimikrobial yang sangat baik (Fook Yee Chye, 2009 : 292).

\section{KESIMPULAN}

Pemberian perlakuan konsentrasi ekstrak biji pangi pada tingkatan konsentrasi 45 ppm merupakan perlakuan yang terbaik, dan sangat mempengaruhi mortalitas kumbang logong (Sitophylus oryzae).

Ekstrak biji pangi dengan menggunakan pelarut $n$-heksan memberikan hasil yang terbaik dalam meningkatkan mortalitas hama kumbang logong (Sitophylus oryzae)

Proses aplikasi ekstrak biji pangi diperoleh hasil bahwa semakin tinggi konsentrasi ekstrak biji pangi ( $P$. edule Reinw.), semakin tinggi jumlah hama kumbang logong (Sitophylus oryzae) yang mati.
Hasil uji pemeriksaan fitokimia yang diperoleh adalah kandungan metabolit sekunder ekstrak biji pangi $n$-heksan dan ekstrak biji pangi etanol, positif mengandung senyawa alkaloid, saponin, tanin dan fenol.

\section{Saran}

Perlu dilakukan penelitian lebih lanjut untuk menguji kandungan komponen ekstrak bij pangi dengan pelarut $n$-heksan maupun dengan pelarut etanol, melalui uji kromatografi gas spektrofotometri massa (GC-MS), agar kita dapat mengetahui lebih banyak mengenai zat toksik lainnya yang terkandung pada biji pangi tersebut.

Perlu dilakukan uji screening fitokimia lanjutan, khususnya untuk mengidentifikasi senyawa metabolit sekunder golongan Flavonoid, Triterpenoid, Steroid, Terpenoid. Disarankan kepada petani untuk menggunakan insektisida nabati berbahan dasar ekstrak biji pangi (Pangium edule Reinw.) dalam mengendalikan populasi hama kumbang logong (Sitophylus oryzae).

\section{DAFTAR PUSTAKA}

Anonimous. 2011. How to Calculate Lethal Concentration 50 (LC50) and Lethal Dosis (LD50)Values. http://www.ccohs.cal oshanswers/chemicals/ld50.html diakses pada tanggal 31 Desember 2011.

Coloma, A.G. Gutierrez, E. De La Pena, and D. Cortez. 2002. Insecticidal and Mutagenic Evaluatiuon of Two Annonaceous Acetogenins. J. Nat. Prod. 63.

Djafaruddin. 1996. Dasar-dasar Perlindungan Tanaman Umum. Penerbit Bumi Aksara ; Jakarta.

Fook Yee Chye and Kheng Yuen Sim. 2009. Antioxidative and Antibacterial of Pangium edule Seed Extracts. School of Food Science and Nutrition, University Malaysia Kota Kinabalu, Sabah. International Journal of Pharmacology (285-297).

Hanafiah, K.A. 2005. Rancangan Percobaan,Teori dan Aplikasi. Edisi Ketiga. Raja Grafindo Persada, Jakarta. 
Hanani, E. dan A. Mun'im. 2005. Penuntun Praktikum Fitokimial. Departemen Farmasi, FMIPA UI. Depok: i + 13 hlm.

Harborne. 1987. Metode Fitokimia Penuntun Cara Modern Menganalisis Tumbuhan. Diterjemahkan oleh Padma Winata,K \& Soediro.I. ITB. Bandung.

Hutabarat, L.N. 2010. Pengendalian Sitophilus oryzae (Coleoptera: Curculionidae) dan Tribolium castaneum (Coleoptera: Tenebrionidae) dengan Beberapa Serbuk Biji sebagai Insektisida Botani. Skripsi. Departemen IImu Hama dan Penyakit Tumbuhan. Fakultas Pertanian. Universitas Sumatera Utara. Medan. http://repository.usu.ac.id/bitstream/ 12345 6789/22516/7/Cover.pdf diakses pada tanggal 1 Agustus 2011.

Indriati, G. dan Khaerati. 2009. Potensi Tanaman Saga (Abrus precatorius) Sebagai Pestisida Nabati. Warta Penelitian dan Pengembangan Tanaman Industri, Volume 15 Nomor 1, April 2009.

Johnny L., Umi Kalsom Yusuf dan Rosimah Nulit., 2010. The Effect of Herbal Exctracts on the Growth and Sporulation of Colleototrichum gloeosporioides. Department Biology, Faculty of Science. University Putra Malaysia, Selangor.Malaysia. Journal Applied Bioscience.

Lily Ismaini. 2007. Uji Bakteri Ekstrak Akuades, Etanol 50\%, dan N-Heksana Biji Picung (Pangium edule Reinw.) Segar dan terfermentasi terhadap bakteri pembusuk ikan. Tesis. Program Pascasarjana Biologi FMIPA Univeristas Indonesia.

Lolombulan, J. 2010. Handout Mata Kuliah Analisis Statistika. Program Pasca Sarjana Universitas Negeri Manado.

Lohoo, B.C.G. 2006. Penggunaan Ekstrak Buah Lanta (Excoecaria agallocha L.) Untuk Pengendalian Hama (Spodoptera exigua Hubner.) Pada Tanaman Bawang Daun (Allium fistulosum L.). Tesis. Program Pascasarjana Program Studi Biologi, Universitas Negeri Manado.
Manoppo, J.S.S. 2003. Pengaruh Ekstrak Akar Tanaman Tuba (Derris elliptica Wallich. (Benth.) Sebagai Moluskisida Nabati Dalam Meningkatkan Mortalitas Keong Mas (Pomacea canaliculata L.) Skripsi. Jurusan Biologi Fakultas Matematika Dan IImu Pengetahuan Alam. Universitas Negeri Manado.

Manoppo, J.L. 2011. Komunikasi personal. Kondisi gudang penyimpanan cadangan bahan pangan Gapoktan Pinaesaan Desa Tonsealama.

Parinduri, M.A. 2010. Uji Efektivitas Beberapa Rimpang Zingiberaceae Terhadap Pengendalian Kumbang logong (S. oryzae L.) (Sitophylus oryzae L.) (Coleoptera: Curculionidae) Di Laboratorium. Skripsi. Departemen IImu Hama dan Penyakit Tumbuhan. Fakultas Pertanian. Universitas Sumatera Utara. Medan. http://repository.usu.ac.id/bitstream/12345 6789/22516/7/Cover.pdf diakses pada tanggal 1 Agustus 2011.

Ramsiks. 2010. Pengaruh Penggunaan Berbagai Warna Cahaya Dan Jenis Beras Terhadap Daya Preferensi Dan Mortalitas (Sitophylus oryzae Linn.) (Coleoptera : Curculionidae) Di Laboratorium. Skripsi. Departemen IImu Hama dan Penyakit Tumbuhan. Fakultas Pertanian. Universitas Sumatera Utara. Medan. http://repository.usu.ac.id/bitstream/12345 6789/22518/7/Cover.pdf diakses pada tanggal 1 Agustus 2011.

Sijabat, V. 2010. Uji Beberapa Insektisida Nabati Terhadap Pengendalian Kumbang Beras (Sitophylus oryzae) (Coeloptera: Curculionidae) Di Laboratorium. Skripsi. Departemen IImu Hama dan Penyakit Tumbuhan. Fakultas Pertanian. Universitas Sumatera Utara. Medan. http://repository.usu.ac.id/bitstream/12345 6789/22618/7/Cover.pdf diakses pada tanggal 1 Agustus 2011. 
Sukandar, D., Sandra Hermanto dan Septiyani Nurichawato. 2007. Karakterisasi Senyawa Aktif Pengendali Hama Kutu Beras (Sitophylus oryzae L.) dari Distilat Minyak Atsiri Pandan Wangi ( $P$. amarylliforius Roxb.). http://jurnal.pdii. lipi.go.id/admin/jurnal/1308127132.pdf diakses pada tanggal 1 Agustus 2011.

Suryaningsih, E. dan W.W. Hadisoeganda. 2004. Pestisida Botani Untuk Mengendalikan Hama dan Penyakit pada Tanaman Sayuran. Balai Penelitian Tanaman Sayuran. Lembang ; Bandung.

Thamrin, M. S. Asikin, Mukhlis dan A. Budiman. 2005. Potensi Ekstrak Flora Lahan Rawa sebagai Pestisida Nabati. Balai Pertanian Lahan Rawa. http://balittra.litbang.deptan. go.id/eksotik/Monograf\%20-\%204.pdf di akses pada tanggal 2 Agustus 2011.

Towaha, J. dan Kurnia Dewi Sasmita. 2010. Pemanfaatan Biji Picung Sebagai Bahan Makanan. Warta Penelitian dan Pengembangan Tanaman Industri. Volume 16 Nomor 3, Desember 2010. http://perkebunan.litbang.deptan.go.id/uplo ad.files/File/publikasi/warta/warta\%202010 /perkebunan_warta_vol16(3)-2010.pdf diakses pada tanggal 1 Agustus 2011.

Tridiyani. 2011. Lethal concentration ( $\left.\mathrm{LC}_{50}\right)$ 3diyanisa3.blogspot.com/2011/05/lethalconcentration-50-Ic50.html
Udarno, L. 2008. Picung (P. edule Reinw.) Sebagai Pengawet dan Pestisida Alami. Warta Penelitian dan Pengembangan Tanaman Industri. Volume 14. Nomor 3. Desember 2008. Ballitri.

Wijayakusuma, H., S. Dalimartha dan A.S. Wirian., 1992a. Tanaman Berkhasiat Obat Di Indonesia. Jilid I. Pustaka Kartini. Jakarta. 1992b. Tanaman Berkhasiat Obat Di Indonesia. Jilid IV. Pustaka Kartini. Jakarta

Widyasari, R.A.H.E. 2005. Teknologi Pengawetan Ikan Kembung (Rastreliger branchyosoma) segar dengan menggunakan bahan bioaktif alami biji picung (Pangium edule Reinw.) Thesis. Sekolah Pascasarjana Institut Pertanian Bogor.

Wudianto, R. 1997. Petunjuk Penggunaan Pestisida. Penebar Swadaya. Jakarta.

Yuningsih. 2008. Kandungan dan Stabilitas Sianida Dalam Tanaman Picung (P. edule Reinw.) Serta Pemanfaatannya. Balai Besar Penelitian Veteriner. http://balittro.litbang. deptan.go.id/ind/images/stories/edsus/vol2 On02/4stabilitas.pdf diakses pada tanggal 29 Juli 2011.

Zulhan, A. 2006. Identifikasi Fraksi Daging Buah Picung (Pangium edule Reinw.) yang aktif sebagai insektisida botani terhadap ulat grayak. (Spodoptera litura F. (Lepidoptera: Noctuidae)). Skripsi. Departemen Kimia, Insitut Pertanian Bogor. 
